\title{
Preliminary Studies on a Virus Disease of a Sapogenin-Producing Dioscorea Species in Puerto Rico
}

\author{
Earl G. Ruppel, Herminio Delpin, and Franklin W. Martin ${ }^{1}$
}

\section{INTRODUCTION}

Tubers of several Dioscorea species constitute one of the major sources of the sapogenin, diosgenin, which is used for the commercial synthesis of valuable therapeutic compounds such as cortisone anicte progesterone (4). ${ }^{2}$ Studies are being conducted at the Federal Experiment Station in Mayagüez, P.R., to increase the diosgenin content of these species through hybridization and selection.

Few serious diseases have been observed during the course of these studies. However, a survey of 227 Dioscorea plants in a field at Las Mesas, Mayagüez, P.R., in December 1963 revealed five distinct xiruslike symptoms in about 10 percent of the plants. The two predominant symptoms included a nondescript mosaic, and a "green-banding" one. The symptoms of the latter disease, by far the most common, consisted of a dark-green banding of the main veins of the leaves, while the interlaminate areas were light yellowish-green (fig. 1). Since the planting consisted of several Dioscorea species and hybrids, it was not evident whether the various symptoms were the results of more than one virus, or of differential responses of the plants.

A second disease survey of the same Dioscorea plants in autumn 1964 revealed a disease incidence of more than 95 percent. All the symptoms observed in 1963 were found again; however, the green-banding symptom greatly predominated. The marked increase in disease incidence precipitated the following studies on the nature and spread of the viruslike diseases. Attention was concentrated on the green-banding disease. In vivo therapy measures were also investigated.

\section{METHODS AND RESULTS}

\section{MECHANICAL TRANSMISSION BX RUBBING}

We attempted to determine whether the different viruslike symptoms observed in the field could be transmitted by the usual rubbing technique.

\footnotetext{
1 Plant Pathologist (present address: Univ. Ariz. Agr. Exp. Sta., Mesa, Ariz.), Agronomist, and Plant Geneticist, respectively, USDA, Agricultural Research Service, Crops Research Division, Federal Experiment Station, Mayagüez, P.R.

${ }^{2}$ Numbers in parenthesis refer to Literature Cited, p. 157.
} 
Wo also made ('ross-inorulations of Dioscorea composila Ilemsi., D), Aloribunda Mar. \& (Gal., and $D$. spiculiftora Hemsl. 10 ascertain whether one or more viruses were responsible for the various symptoms in the field. We prepared inoculum of ach symplom-type by marerating leaves of Dioscorea species or hybrids with a mortan and pestle in 0.05 -mol phosphate buffer $(p \mathrm{H} 7.0$ ) rontaining $0.01-\mathrm{mol}$ cysteine hydrocbloricle (5 gm. tissuc
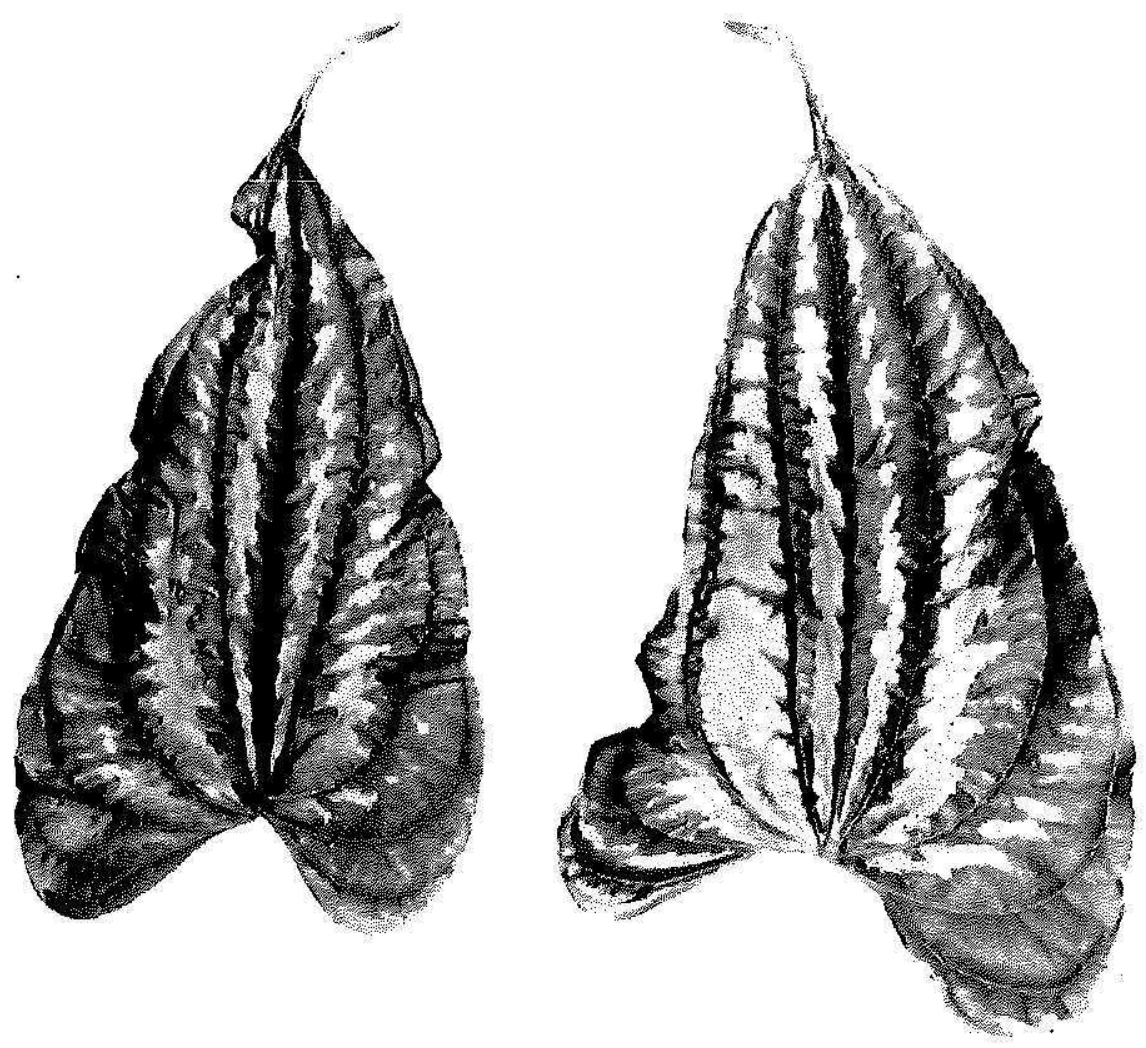

Fra. 1.-Teatves uf Diosrorea romposilu naturally infected with the green-banding virus. lenves of healthy plants ate uniformly green.

per I inl. buffer). listeb inorulum was rubbed onto the rabortundum-dusted leaves of three plants of each sjecies wilh small checiserloth pads. Au addirional carbortundum-dusted plame of each species was nobbel wilh buffer(ystcine hydrochloride solution for romtrols.

One plant of $D$, composita and one of 1$)$. florilunda rubbed wilh inoculum from mosilicdiscased plants developed grecu-bauding symptoms. One plaul of 7 ). composila and (wo of $D$. ftoribunda, when rubbed with inoculum from plants exhibiting the green-hatuding :xmplom, cleveloped the greenbandiug discasce. Transmission of the other viansike discense: merhanically 
by salp inoculation was unsteressful. The rewults indieate that the mosatio: and green-banding symploms were induced by the same virus, which was manced the Dioseorea green-banding vinus (I)(iBI).

'Transmission of 1$)$ (iB)' in thee additional fosis with inoculum from infectod D. compesila plank: was bow and exatic. In one fest, mly one of live inoculated plants of 1 ). composita became infected, and only one of live inoculated D. floribunda plauts was infered in a second lest. None of five 1). composila plants berame intected in a third test.

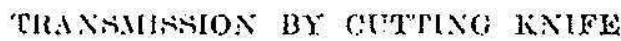

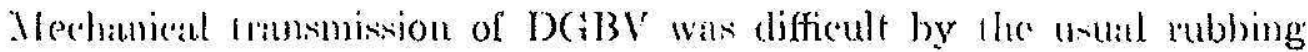
ferhnique. Veveltheless, some sucess was obtaned. Conseguently, we altempted thusmission of the virts by a rulling-linite, one of the ustal mathods of luber mopagation in the ficld. To test such tratnmission, 10) D) CBV-infected tubers of $D$. composila were cut in hall with a knife. Then 10 healthy grecnhouse-grown lubers were cut with the sanc knife. All uber halves were planted in individual pots and the developing vines were observed for virus symploms. After is months we observed no evidenee of virus lansmission by means of the cutting-knife. Only vines from previously intected tubers exhibirel virus symptoms.

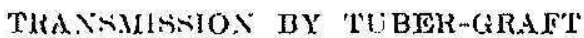

We removed lissue cylinders $(8 \times$ i) mm.) from DGI3/-interted tubers of 1). Joribunda with a sterile cork burer, and similax cylinders from beallhy t.ubers. IVe inserted the cylinders from the diseased fuber's into the fualtuy lubers, aud those from the healthy hubers into the diseared tuburs. We rovered the wounds with anhydrous Jasolin to prevent desiceation, aus planted the tubers (five replications) in individual pols.

Only two of the five previously healthy cuber's germinaled, and linese leveloped typieal D)(iBV symptoms, which indicated sureessid lamsmission through the fuber-grafts.

HOST HANGE

live plants euch of Capsicum annum L. 'California Wonder', C'rolalaria juncea L., C. striala DC., Cucumis satizus I. 'PTR 39', Dinscorea floribunda, 1). spiculifora, Gomphrena globosa [.., Tycopersicon esculenlum Mill. 'Al.om', Vicotiana glutinosa l., N. Labacum L. 'Havana 38', Phaseolus mulgaris T., and Vigna sinensis (Torner) Sivi. were dusted with carborundum and inoculated with sap extrated from DCBTV-inlected laves of D. composila. IVe also inoenlated healthy D. composita plants to chere the viability of the inosulum. Two plants of cach species, dusted with ribborumelum and rubbed with buffer, served as controls. 
()nly (․ striala, D). composila, D). floribumela, and X. glutzuosa developed

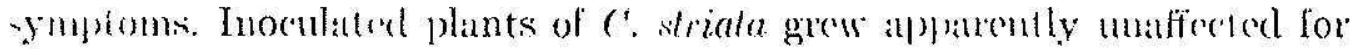

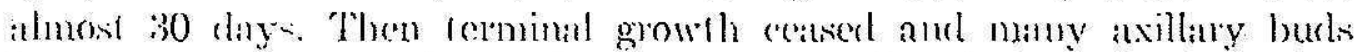

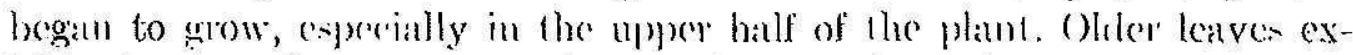
hibited rein-yollowing or a mild molling. Lafeds of the axillary shoots

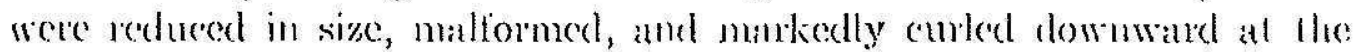
margius. Thorulated D). floribunda flimls, and the D). compesila rontrol

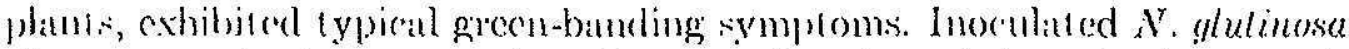

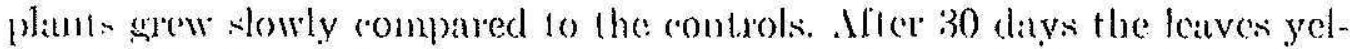
lowed, wilted, and then became neerotice, begimning at the bate of the plant

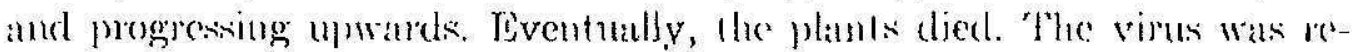

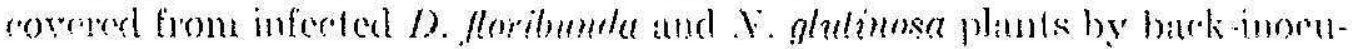
lat ion (o) D). composila.

fuosulated S. labacum platus remained symplombers; however, lhe

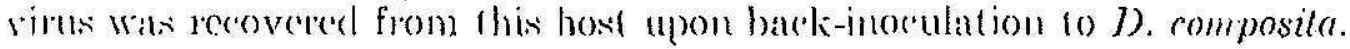

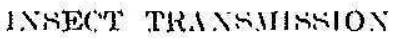

The rolton athich (aphis gossypii (ilov.) of en was observed infesting bioserea vines in the lats Meses areat. The rapid spreat of the virus in

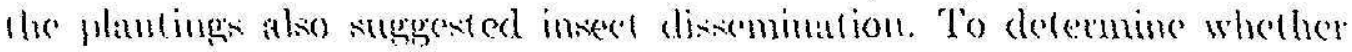

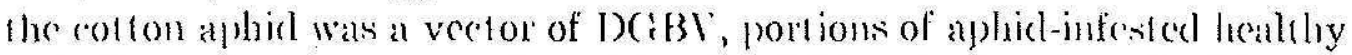
and discased vines were colleeted in the fiedd and placed on healthy $D$. composila plants in insectprool' atges in the garenhoure. Approximately

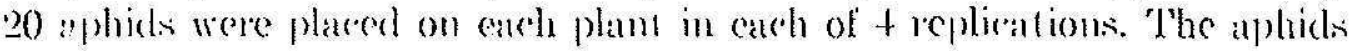
leff the dying vines and infested the houlthy plants. After I week all the aphids hat died. Xo aphid multiplieation oceured on the plants.

Two plats inforted with aphids from discased field pants developed 7) (il3V s.mploms within 30 days. All ot her plants remaned houlthy. These rexults steggested that some of the aphids transtered from disetsed fictd

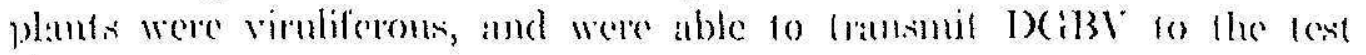
Hlituls.

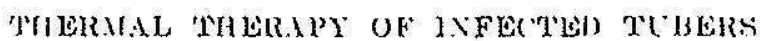

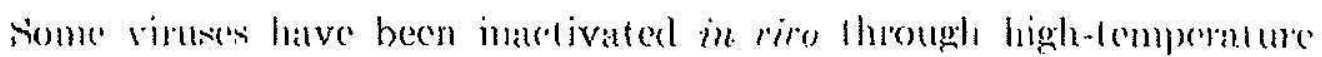
treatment of whole plauts or phant pats $(2,6,7,8,9,10)$. Wr allempled to

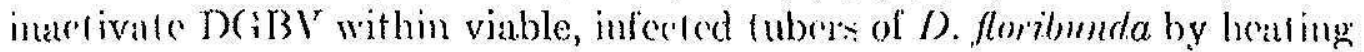
them in a walle bath at $50^{\circ} \mathrm{C}$. for $5,10,30$, and 60 minute. IVe: healed four heallyy and fowe infected tubers at careh lime interval and then immexerl them in ice water for is miuntes before planting in individual pots

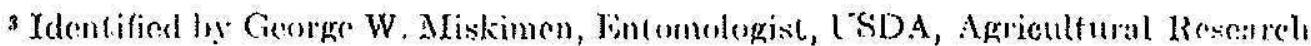

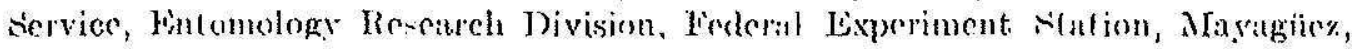
P.R. 


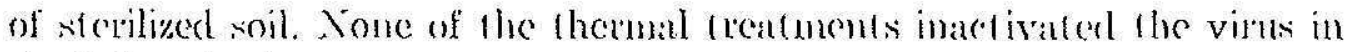
the inierered tuber's.

In another (xpleriment we phaced six henlthy and six 1)(:13V-inforted lubers of $D$. floriburla for 2 woeks in an. incubator at $37^{\circ}(:$ will a high redative humidity. We planted the fubers and obsorved the gemmiting vines for viru- svmptoms. Three heillby and hree infected fubers germimared. All of the former produced beathy vines, while the latter produred vines wilh D(ibl' symploms.

\section{DISCASSION}

The green-banding virus of Dioscorea was extremely difficult to transunt

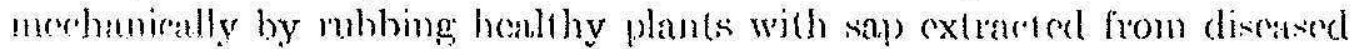
pamts. ('ysteine hydrochloride, a strong leduring agent, was adeled to the inosulum to rounferuet the rapid oxidation that oceures when Dioscorea

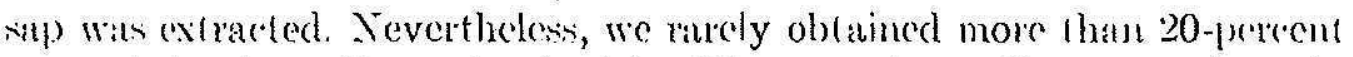
mansmission from discased to hesthy Dioscorea plants. Consequently, only positive results in the host-range sturlics are ronsidered significant.

The positive infection of $C$. striala may have special significane'e. This plant is a common weed growing in the Lats Mesis arca and in olher parts of Pucrto Rir:o. Further studies may reveal that this plant rorves as a renervoir for the Dioscorea virus. This species may also prove uscful as a soures-plant for inoculum in fulue invertigations.

The raming of cotton aphidis on eaged plants in the greenhouse wats not leatsible. Thus, we could make only preliminary tests. The meager evidence obtaned, however, suggests that aphids are rewponsible for the mpid sproud of the vitus in the field. Wore prerise aphid-lausmission studies are neesssury to confirm the mode of virus dissomination.

Thermal-1herajy treatments under the conditions of our study failed to iuastivate the virus in rivo. However, the longer thermal periods tended 10 stinulate tuber germination. Only two of eight tubers (healthy and infected) sprouted after a 5-minute treatment; there of eight affer $10 \mathrm{~min}$ ut ('s; right of right after 30 minules; and six of cight affer 80 minutes. Thus, higher temporatures or longer durations eould be weel that may prove more offertive in liming lubers from the virus.

The difficuly in trasmitling the virus by sap-iusculation prevented studies of physical properties of the virus. Consenuently, it was impossible to compure ou Dioscorea virus with that reported by Adsulu $(t)$. However, he reported sucessful infection of Cucumis salious, wherens oux Irst with this specion was negalive. Since we were unable to gominate lubers of D. rohmolata P'oir, symplom comparisons between our isolate rould not be made with Adsume's virus, which produred a mosaic of this host. Howererr, our isolate juduced the gren-bunding symplom in all Dioscorea species 
in the find, imeluding 1). (amposita, 1). foribunda, 1). friedrichsthatii, anu D). spiculiftera. Nevertheless, the oreasional induetion of mosite symproms by our isolate may indieate that it is identional with the one reproted by delsuar.

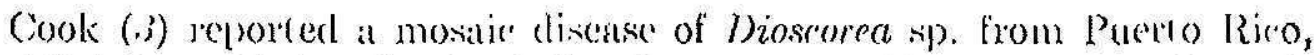
and Deighton (ij) described a smilar direase from dirica. Since these inverati-

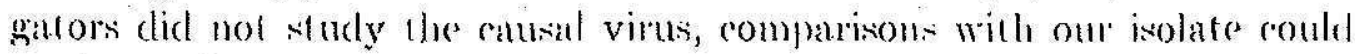
not be made.

\section{SIMINRY}

V'irus incidence indreased from 10 to more than 9.5 pereent in a ficleplanting of Dinerorea spp). between 1963 and $19(4+$. The pretominant symptom consisted of dark-green bands of tissur botdering the man veins, while the interlaminate arens of the leaves weye yellowish-geren. 'The virus was mechanisally lansmitled to Dioscorea composila, D. foritunda, ('rolalaria striala, Vicotiana glulinosa, and $V$. labacum. $N$. labacum was a symptomless host. Symptoms obscrved on D. iriedrichsthatii and D. spiculiffora in the field were similar 10 those observed on other Dioscorea sipl). in the greenhousc. ( $\therefore$ striata, a common weed in Puerto Rico, may serve as it rescrvoil for the virus. The virus was not l lansmilled with a tuber-rulling knife from discased to healthy tubers, but transmission was effected through tuber-gitils. The virus could not be inaclivated in wo with high temperature tratments of the tubers. Preliminary eviden'e suggested that the virus is (mansmitted by the colton aphid (4 phis yossypii).

\section{RESUMLN}

Lar incidencia de un virus que ataca el ñame aumenló do menos de 10 a más de 95 por ciento en una siembra de name (Dioscorea spp).) que s" sembró en 1963 y se coscchó en 1964. El símtoma predominate consistió de franjar verde obsruras en el tejiclo próximo a las venas principales, mieutrux que las áreas interlaminadas de las hojas eran de un color verdeanarillento. El virus se transmitió mecánic'umente a lubérculos de Dinscorea composila, D. floribunda, C. striala, Nicotiana glulinosa y .V. labacum. N. labarum no reveló ningún síntoma del virus. Sc obscrvaron síntomas similares en $D$. friedrichsthali y $D$. spiculiflora, en el 'ampo, así como en otras' especies de Dioscorea en el invernadero. C. striata, un yerbajo ('omún en Puerto Riro, puede scrvil como fuente de rontaminación del virus. Iil virus no se transmitió de los tubérculos enfermos a los sanos con la cuchilla que se usó para cortalos, sino mediante la implantación de injertos a los tubérculos. 1\% virus no se puede inactivar in rivo sometiendo los fubérculos a altas temperaturas. Ina evidencia preliminas pureció indicar que el virus lo trausmite el pugón del algodón (A phis gos:ypii). 


\section{IITERATURE CITEN}

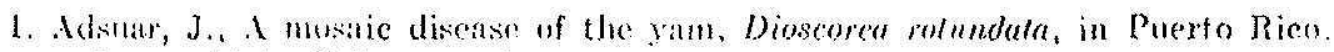
f. Igr. I'nir. I'.K'. 39(3): 111-3, 1955.

2. - Susceptibitity of some sugarcane varjeties fo the heat treatment usced in the cont rol of chlorotic streak, f. Agr. Vhir. P.R., 40(1):67-9), 1950.

3. Cook, M. T., Amn. Rept. Agr. Kxp. Sta. Lniv. D’. R., Rín Piedras, 1935-36, pj). $39-46,1937$.

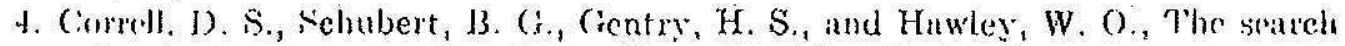
for plant precursors of eurt isune, Econ. Bot. 9(4): 307-75, 1955.

5. 1)cightun, F. C., Rept. Deryt. Agr., S. Leone, 1935, pp. 22-6, 1936.

6. Holmas, F. O., Ruse mosaic cured by heat trentments, Plaml Dis. Reptr. 44(1): $46-7,1960$.

7. lisssmix, 13., Tonato tubers freed from leaf-roll virus by heal, lature 164: 881, $19+49$.

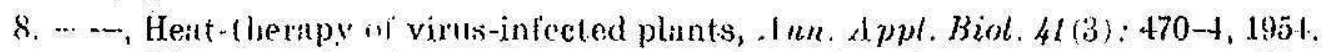

9. -..-. liffects of clanging temperature on plant virus diseases, Admenes in l'irus lies. 4: 221-42, 195i,

10. Kinkel, L. O., Heat treatmonts for the enre of yollons and other virus discases of peuch, Phytopatholog!i, $26(9): 809)-30,1936$. 